\title{
Fostering School Belonging in Secondary Schools Using a Socio-Ecological Framework
}

Kelly-Ann Allen, Dianne Vella-Brodrick and Lea Waters

The Melbourne Graduate School of Education, The University of Melbourne, Australia

The benefits of belonging and feeling connected to school for adolescent mental health and wellbeing are well documented, but how belonging is fostered is less understood. The present article puts forward a new conceptual framework of school belonging based on Bronfenbrenner's (1979) sociological model of human development, using evidence from a range of previous peer-reviewed studies to better understand the factors that occur across five levels that affect a students' sense of school belonging (i.e., the individual level, the microsystem, the mesosystem, the exosystem, and the macrosystem). The conceptual framework is used to present a range of evidence-based school belonging strategies (some with examples) that schools can use to enhance student belonging. This article makes an original contribution to the field of psychological and educational research by presenting a socio-ecological framework to explore the themes that influence school belonging within a secondary school system. It broadens the frame of reference of school belonging beyond the individual student to consider features of the broader school system and environment.

Keywords: belonging, school belonging, school connectedness, academic motivation, school leadership

Belonging has been described as the need for positive regard from others (Rogers, 1951), affiliation motivation (McClelland, 1987), and the desire for relatedness (Vallerand, 1997). Friedman (2007) described a sense of belonging as the development of the self and identity building. It is a well accepted that sense of belonging is not dependent on participation with, or proximity to, others. Rather, it relies on perceptions about the quality of social interactions (Baumeister \& Leary, 1995). Therefore, belonging could be considered as one's perception of his or her involvement in a social system or environment (Hagerty, Lynch-Sauer, Patusky, Bouwsema, \& Collier, 1992).

An extensive review of the literature demonstrates that belonging is an important construct, not only at a theoretical level, but also at an empirical level (Hagerty, Williams, \& Oe, 2002; Hale, Hannum, \& Espelage, 2005). A marked proportion of the psychological literature suggests that general belonging is a vital component of psychological and physical health, and these effects are typically sustained (Daley \&

Received 30 March 2016; Accepted 11 May 2016; First published online 10 June 2016

Address for correspondence: Kelly Allen, c/- Toorak College, PO Box 150, Mount Eliza Vic 3930, Australia. Email: kellya@toorakc.vic.edu.au. 
Buchanan, 1999; Poulton, Caspi, \& Milne, 2002; Wadsworth, Thomsen, Saltzman, Connor-Smith, \& Compas, 2001).

A sense of belonging is considered to play a fundamental role in adolescent development, particularly in respect to identity formation (Brechwald \& Prinstein, 2011; Davis, 2012), psychosocial adjustment, and transition to adulthood (O'Connor, 2010). The literature has also demonstrated that school belonging, more specifically, is an important factor in the successful psychosocial adjustment of young people and presents a purpose for schools to engage in interventions and strategies that might promote belonging to school (Lonczak, Abbott, Hawkins, Kosterman, \& Catalano, 2002; Nutbrown \& Clough, 2009; O’Connor, 2010; O’Connor, Sanson, \& Frydenberg, 2012; Sari, 2012).

It has been argued that schools play an important role in fostering a sense of belonging for students (Allen \& Bowles, 2013) because they are important institutions that can build social networks for young people. Yet, in a review of the literature concerned with school belonging, Allen and Bowles (2013) have argued that the importance of a student's sense of belongingness to school has not been given the same degree of attention as a student's academic success. This finding is consistent with the lower level of attention devoted to other areas of preventive interventions in schools, such as health promotion and social and emotional learning (Collaborative for Academic Social and Emotional Learning [CASEL], 2003; Hagerty et al., 1992; West, Sweeting, \& Leyland, 2004). Very few examples of interventions aimed at specifically increasing a student's sense of belonging can be found at the secondary school level in Australian schools (e.g., SenseAbility; Beyond Blue, 2014); however, the absence of school belonging in whole-school intervention programs appears to be a universal issue, with very few examples in the literature (e.g., Centres for Disease Control and Prevention [CDC], 2009). One reason why school belonging is seldom examined in schools could be due to the absence of a model or framework that schools can employ to foster belonging in students. The field of school belonging research in this respect is largely theoretical, and this may be one factor that restricts the development of belongingness interventions (e.g., in addition to definitional and measurement issues).

Clearly, there is a need for frameworks that assist schools to foster school belonging. Yet, only a small number of conceptual frameworks have focused on school belonging at the student level (e.g., motivation, individual characteristics, emotional instability; Brendtro, Brokenleg, \& VanBockern, 2002; Connell \& Wellborn, 1991; Malti \& Noam, 2009; Ryan \& Deci, 2000). Further, these frameworks are limited because they have focused on school belonging as an internal, intra-individual phenomenon and, thus, have not accounted for relational factors and broader aspects in the school environment that influence a student's sense of belonging. While a few frameworks have recognised the importance of school resources and support (e.g., CDC, 2009; McMahon et al., 2008; Wallace, Ye, \& Chhuon, 2012), very few of these frameworks have presented school belonging as a multidimensional construct within a multilayered social ecology based on empirical evidence (e.g., Rowe, Stewart, \& Patterson, 2007; Waters, Cross, \& Reunion, 2009).

\section{The Socio-Ecological Framework of School Belonging}

We propose that school belonging is a student's sense of affiliation to his or her school, influenced by individual, relational, and organisational factors inside a broader school 
community, and within a political, cultural, and geographical landscape unique to each school setting. Put more simply, school belonging is one's feeling of being connected to a school within a school social system.

In this conceptual paper, we propose that school belonging is a multilayered socio-ecological phenomena, and we apply Bronfenbrenner's (1979) ecological framework for human development to school belonging in order to explore the various layers that affect a student's sense of school belonging. Bronfenbrenner's ecological framework for human development is concerned with systems in society and suggests that for young people, the family is the first unit to which children belong. This is followed by school and community, with each student belonging to a broader network of groups and systems.

All children are at the centre of multiple levels of influence (i.e., the microsystem, mesosystem, exosystem, and macrosystem) and schools can have a significant effect on their development and psychosocial adjustment (Bronfenbrenner, 1979). Bronfenbrenner's (1979) ecological framework for human development serves as a reminder that within any school setting, each student is a part of a greater whole influenced by formal and informal groupings, and overarching systems that are common and typically represented within all schools.

Socio-ecological frameworks such as Bronfenbrenner's (1979) emphasise the importance of social relationships but also include tangible environmental, physical, and ecological variables, such as classrooms and resources (Bronfenbrenner, 1979). The socio-ecological layers represented in such frameworks may provide a structure for schools to improve school belonging by working at the level of the individual, working with interpersonal relationships (e.g., peer, teacher, and parent), and addressing whole school approaches (Saab, 2009; Waters et al., 2009; Waters, Cross, \& Shaw, 2010).

Bronfenbrenner's (1979) ecological framework for human development provides the most widely applied theoretical construct to date with which to investigate belonging in an organisational setting such as a school, while acknowledging the innate desire humans have to belong (Baumeister \& Leary, 1995; Saab, 2009; Waters et al., 2009; Waters et al., 2010). This may be because Bronfenbrenner's socio-ecological framework represents the varied layers and systems within a school whereas other models and frameworks may only examine constructs directly related to the individual student (Brendtro et al., 2002; Malti \& Noam, 2009).

The current conceptual paper proposes a socio-ecological framework of school belonging (Figure 1) to explore school belonging at the individual (through individual characteristics), microsystem (through relationships with parents, peers, and teachers), mesosystem (through school rules and practices), exosystem (through the extended school community), and macrosystem levels (through legislation, social norms, and government initiatives such as the nationally collected data on academic achievement).

The framework can be used by educators, school leaders, and school psychologists to intervene at various levels across the school to enhance school belonging. It also provides an organising framework for researchers in the field to categorise the many different research findings on school belonging at the individual, classroom, and organisational levels. Such a classification system will benefit schools and shed light on which layers within the schools should be prioritised. 


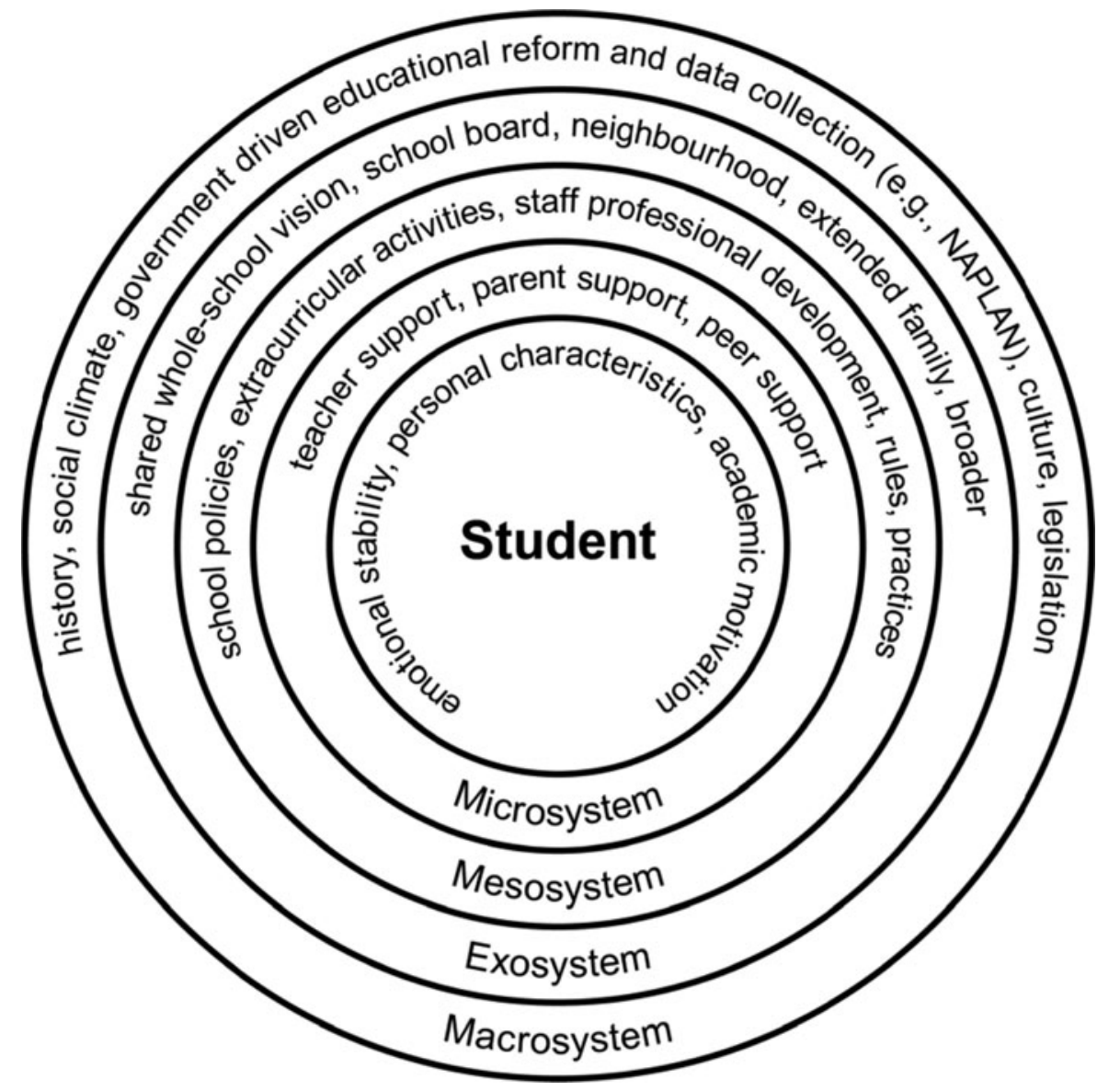

FIGURE 1

The socio-ecological framework of school belonging.

While there is plenty of research supporting the importance of school belonging, very few attempts have been made to understand how it can be fostered. Previous studies (Goodenow, 1992; Hurtado \& Carter, 1997; Juvonen, 2006) have only focused on the definition, measurement, and importance of school belonging without identifying the precursors and methods for fostering a sense of belonging in school settings. Therefore, this article attempts to address this research-practice gap in schools by specifically looking at the themes that foster school belonging through Bronfenbrenner's (1979) socio-ecological framework for human development. This article also endeavours to draw upon existing empirical research to support the development of a framework. The translation of findings into an evidence-based framework can assist schools to address the research-practice gap and provide the necessary antecedent conditions for fostering school belonging (Hirschkorn \& Geelan, 2008; Rowe \& Stewart, 2011). Conceptual frameworks can be viewed as theories in their early stages, according to Sharma and Romas (2008), and as such, they should use empirical evidence and be subject to ongoing testing to further develop an evidence base. 
The framework used to support the socio-ecological framework of school belonging is based on the work of Wingspread Declaration on School Connections (2004), the Centers for Disease Control and Prevention (2009), as well as other research and various measurement instruments of school belonging (Appleton, Christenson, Kim, \& Reschly, 2006; Goodenow, 1992; Libbey, 2004; McNeely, Nonnemaker, \& Blum, 2002). This thematic framework represents a sample of important tiers in the literature on school belonging to broadly explore the question: What themes influence school belonging? The studies that informed the development of the socioecological framework of school belonging were sourced from electronic databases such as EBSCO's Discovery search layer, including Ovid Medline, Mental Health Abstracts, PsycINFO, Social Sciences Abstracts, Sociological Abstracts via SocioFile, Academic Search Premier, Social Sciences Citation Index, and ERIC. Studies were sourced from English-speaking countries and published within the last 20 years. Therefore, a broad range of studies have been used to support the development of the socio-ecological framework of school belonging.

\section{The Layers and Their Interactions}

The socio-ecological framework of school belonging outlines five levels of interconnected layers within an ecology that supports school belonging. The levels start with the individual and move in concentric rings outwards through the microsystem, mesosystem, exosystem, and macrosystem. The five layers of the socio-ecological framework of school belonging and associated evidence based practices will be discussed below.

\section{Individual}

The inner portion of the socio-ecological framework of school belonging represents the individual student and associated individual-level themes that relate to his or her sense of school belonging. Past literature indicates three distinct aspects within an individual student that have been found to correlate with school belonging: academic motivation, emotional stability, and personal characteristics (social and emotional competencies).

Academic motivation includes variables related to performance, objective measures (e.g., test scores and grades), classroom engagement, and perceived value and usefulness of the curriculum and school (Wingspread Declaration on School Connections, ${ }^{1}$ 2004). Gillen-O’Neel and Fuligni (2013) performed longitudinal within-person analyses with 572 young people aged between 13 and 19 years over a 4 -year period. The results suggested that school belonging was positively associated with a higher level of perceived academic value. The authors suggest that when young people feel connected to their school, they are more likely to find school useful and be academically motivated.

Emotional stability is defined as the absence of maladaptive behaviour, psychopathology, or persistent distress, thus including the absence of mental illness (Cole, Llera, \& Pemberton, 2009). One example of an emotional instability variable that has been studied in the literature on school belonging is anxiety where a consistent inverse relationship has been found within its association with school belonging (Williams \& Galliher, 2006; Lee \& Robbins, 2000). It is unlikely that schools will use the term emotional instability in policy and practice. Instead, schools are more likely to build emotional stability and use terminology based on psychological health and 
wellbeing (Donovan, 2011). This is why the term emotional stability has been used in the framework of school belonging rather than emotional instability. Emotional stability has not been examined in previous frameworks of school belonging; therefore, the socio-ecological framework of school belonging is unique in that it represents this important theme.

The third theme at the student level that has been shown to relate to school belonging involves personal characteristics (i.e., social and emotional competencies), such as coping skills, positive affect, self-efficacy, self-esteem, and self-concept (Hawkins \& Weis, 1985; Faircloth, 2009; Reschly, Huebner, Appleton, \& Antaramian, 2008; Samdal, Nutbeam, Wold, \& Kannas, 1998; Sirin \& Rogers-Sirin, 2004). Frydenberg, Care, Freeman, and Chan (2009) found that students who engaged in productive coping (i.e., the ability to successfully regulate behaviours, cognitions, and emotions in response to daily stressors) were more likely to exhibit a greater sense of belonging to their school. Other research (e.g., Reschly et al., 2008; Ryzin, Gravely, \& Roseth, 2009) has demonstrated that positive emotions like optimism, hope, and hopefulness are positively associated with school belonging as well. Reschly et al. (2008) identified that social and emotional competencies such as having a positive affect and productive coping skills play an important role in fostering school belonging and vice versa. Therefore, when schools engage in practices that encourage academic motivation, build emotional stability, and foster certain personal characteristics (e.g., coping skills, self-efficacy, self-esteem, and self-regulation), this will likely increase the students' sense of school belonging.

The direction of the relationships between academic motivation, emotional stability, and personal characteristics with school belonging has not been accurately determined from past research, but it is likely the relationship is bidirectional (e.g., Goodenow \& Grady, 1993; Ryan, 1995; Klem \& Connell, 2004; Zimmer-Gembeck, Chipuer, Hanisch, Creed, \& McGregor, 2006). As such, it is suggested that while academic motivation, emotional stability, and personal characteristics may increase a sense of school belonging, school belonging may also lead to an increase in academic motivation, emotional stability, and personal characteristics (such as self-esteem and self-efficacy). Schools seeking to build school belonging can do so by creating high academic motivation, building strong emotional stability, and fostering personal characteristics of students.

Table 1 outlines a set of evidence-based practices designed to increase school belonging at the individual (student) level, based on the three themes of academic motivation, emotional instability, and personal characteristics (Caraway, Tucker, Reinke, \& Hall, 2003; Zimmer-Gembeck et al., 2006; Sirin \& Rogers-Sirin, 2004). That is, these practices are directed at the student and designed to boost his or her academic motivation, cultivate emotional stability, and foster personal characteristics such as coping skills, self-esteem, positive affect, and prosocial goal behaviour. Future intervention studies are needed to confirm the potential for academic motivation, emotional stability, and personal characteristics to increase school belonging, but Table 1 represents key independent variables found in studies that have examined school belonging that have reported a significant and positive relationship and have reported medium to large effect sizes (medium $\geq .30$, large $\geq .50$, Cohen, 1988) ranging from $r=.32$ to $r=.72$. These variables are presented alongside effective evidence-based practices identified in previous research derived from the literature. 
TABLE 1

Individual Level Practices Associated With Socio-Ecological Framework of School Belonging

Target area Evidence-based practices that can increase school belonging

Independent variables

Academic Encourage students to have high (developmentally appropriate) expectations of their

motivation own academic ability. Engage in practices that motivate students to aim to do well. Communicate expectations concerned with learning and behaviour. Apply flexible teaching methodologies and personalise learning. Use consistent positive messages that encourage students to achieve their personal best.

Assist students to understand the benefit and purpose of what they are learning in relation to long- and short-term outcomes (i.e., perceived instrumentality) and lesson goals.

Express a belief that what is being taught is important and valuable. Ensure that teachers are allocated to subject areas that they are interested and passionate about. Relate information to the students' real world and experiences.

Apply mastery goal orientation in the classroom so that students have opportunities to set goals, acquire skills to master those goals, and set further goals. Use teacher feedback to motivate students towards their goals. Emphasise student progress and help students have a good understanding of where they are in their progress and where they are headed next.

Foster motivation through specific classroom interventions designed to motivate students (e.g., student-directed and strength-based learning). In addition, present novel and interesting learning opportunities to students that are based on studen interests and abilities. Engage students through interactive approaches such as role play, group work, and problem solving. Teach skills and strategies related to academic motivation, competence and effective study (i.e., positive self-talk, goal setting, time management, organisation, help seeking). Encourage intrinsic rewards from learning by seeking feedback of student work from other students, teachers, parents, and the local school community.

Teach students skills related to self-regulation to assist in self-monitoring of their academic behaviour and motivating themselves. These skills can be taught by using reward systems and checklists to ensure they are on task and/or working towards acquiring the skills to achieve their goals. Enable students to develop skills that will assist them to prepare for class with the right material and resources.
Self-academic rating

and education goals

Heaven, Mak, Barry, and

Ciarrochi (2002)

Klem and Connell (2004)

Guthrie and Davis (2003)

Perceived

Instrumentality

Valuing academics

Mastery Goal

Orientation

Walker (2012)

Battistich, Schaps, Watson, and Solomon (1996)

Whitlock (2006)

Wentzel (1998)

Dweck, 1986)

Motivation

Battistich et al. (1996)

Goodenow and Grady (1993)

Patton et al. (2006)

Academic

self-regulation
Ryzin et al. (2009) 
TABLE 1

Continued

\begin{tabular}{|c|c|c|c|}
\hline Target area & Evidence-based practices that can increase school belonging & Independent variables & Related studies \\
\hline & $\begin{array}{l}\text { Provide career guidance and counselling services to students in respect to setting } \\
\text { long-term goals and career ambitions. }\end{array}$ & Future aspirations & Reschly et al. (2008) \\
\hline \multirow{19}{*}{$\begin{array}{r}\text { Emotional } \\
\text { stability }\end{array}$} & Implement mental health promotion activities and interventions using a whole-school & Depressive symptoms & Kaminski et al. (2010) \\
\hline & approach (e.g., Act Belong Commit, www.actbelongcommit.org.au). Adopt specific & & Kelly et al. (2012) \\
\hline & evidence-based programs that target skills related to self-care, resiliency, social & & Kuperminc, Leadbeater, and \\
\hline & connectedness, managing stressors, and resolving conflict. Some specific examples & & Blatt (2001) \\
\hline & include Mindmatters (www.mindmatters.edu.au), Coping for Success (Frydenberg, & & Shochet, Dadds, Ham, and \\
\hline & 2011), and Thinking Skills for Peak Performance (Brandon, 2012). & & Montague (2006) \\
\hline & & & $\begin{array}{l}\text { Shochet, Smith, Furlong, and } \\
\text { Homel (2011) }\end{array}$ \\
\hline & $\begin{array}{l}\text { Educate staff to identify early warning signs of mental illness, implement mental health } \\
\text { first aid, and understand appropriate referral and response pathways for students at }\end{array}$ & $\begin{array}{l}\text { Emotional } \\
\text { distress/problem }\end{array}$ & $\begin{array}{l}\text { Education Development } \\
\text { Center (2008) }\end{array}$ \\
\hline & risk. Train key staff members in postvention (i.e., interventions conducted after a critical & Stress & Waters et al. (2010) \\
\hline & incident, to restore wellbeing when managing a critical incident). Encourage staff to & Fear of failure & Wentzel (1998) \\
\hline & proactively reach out to students who may be exhibiting signs of stress or distress. & Psychoticism & $\begin{array}{l}\text { Wilkinson-Lee, Zhang, Nuno, } \\
\text { and Wilhelm (2011) }\end{array}$ \\
\hline & & & Roche \& Kuperminc (2012) \\
\hline & & & Caraway et al. (2003) \\
\hline & & & Heaven et al. (2002) \\
\hline & Encourage student help seeking behaviours across the school. Enable students to know & & \\
\hline & where to access key staff members to seek personal support when needed (i.e., school & & \\
\hline & counsellor, psychologist, chaplain). Ensure that these individuals are known within the & & \\
\hline & school community (e.g., they may participate actively in other school-based activities & & \\
\hline & $\begin{array}{l}\text { that are not directly related to counselling) to reduce stigma for students seeking these } \\
\text { services. }\end{array}$ & & \\
\hline
\end{tabular}


TABLE 1

Continued

\begin{tabular}{|c|c|c|c|}
\hline Target area & Evidence-based practices that can increase school belonging & Independent variables & Related studies \\
\hline \multirow[t]{5}{*}{$\begin{array}{l}\text { Personal char- } \\
\text { acteristics }\end{array}$} & $\begin{array}{l}\text { Ensure that students understand that they have a role to play in fostering their own sense } \\
\text { of school belonging. This can be done through psychoeducational opportunities } \\
\text { provided by the school, social and emotional learning, small group interventions, or } \\
\text { individual counselling that specifically address the key themes found to foster school } \\
\text { belonging (e.g., academic motivation, emotional stability, personal characteristics, and } \\
\text { support from others) as well as boosting individual social and emotional competencies. }\end{array}$ & Self-esteem & $\begin{array}{l}\text { Ryan, Stiller, and Lynch (1994) } \\
\text { Sirin \& Rogers-Sirin (2004) }\end{array}$ \\
\hline & $\begin{array}{l}\text { Encourage students to identify their individual character strengths and provide } \\
\text { opportunities for them to apply them within curricula and co-curricula activities. } \\
\text { Character education has been shown to increase self-efficacy and self-esteem. }\end{array}$ & & Proctor et al. (2011) \\
\hline & $\begin{array}{l}\text { Teach students about the benefits associated with a positive mindset (i.e., their beliefs } \\
\text { and attitudes). For example, encourage students to view errors and mistakes as } \\
\text { learning opportunities. }\end{array}$ & & Dweck (1986) \\
\hline & $\begin{array}{l}\text { Engage students in setting personal goals related to their wellbeing in addition to goals } \\
\text { set around their academic outcomes. Interventions can occur within the school that } \\
\text { foster positive relationships, coping skills, adaptability, resilience, and positive } \\
\text { prosocial behaviour. }\end{array}$ & $\begin{array}{l}\text { Prosocial goal pursuit } \\
\text { and behaviour }\end{array}$ & $\begin{array}{l}\text { Wentzel (1998) } \\
\text { Zimmer-Gembeck et al. } \\
\text { (2006) }\end{array}$ \\
\hline & $\begin{array}{l}\text { Consider the use of positive psychology interventions to foster optimism, hopefulness, } \\
\text { and happiness (see Seligman, 2011). These interventions can include gratitude } \\
\text { curricula, giving to others, and savouring what went well routines (Nielsen, 2011). }\end{array}$ & Positive affect & $\begin{array}{l}\text { Heaven et al. (2002) } \\
\text { Reschly et al. (2008) } \\
\text { Ryzin et al. (2009) } \\
\text { Stoddard, McMorris, and } \\
\quad \text { Sieving (2011) }\end{array}$ \\
\hline
\end{tabular}

Note: Practices are derived from the literature as indicated.

Sieving (2011)
(2) 


\section{Microsystem}

The importance of a student's relationship with parents, peers, and teachers has been illustrated through various frameworks incorporating school belonging (e.g., CDC, 2009; Connell \& Wellborn, 1991). One example is the Self-System Process Model applied to educational settings by Connell and Wellborn (1991). Elements of this model include relationship skills with peers and adults, self-awareness of feelings, emotional regulation, and conflict resolution skills. Thus, it is clear that both the individual and microsystem levels work together to foster school belonging.

Brophy (2004) encourages educators to enhance students' positive dispositional traits such as initiative and self-perceived competence, which contribute to social interactions and relatedness to adults and peers within a school setting. Through Brophy's work, based on a systematic review of motivational literature, the findings suggest that the individual and microsystem levels of the socio-ecological framework interact, because when a school builds the personal characteristics of self-perceived competence (e.g., self-efficacy, self-esteem, and self-concept), this increases the students' relational skills. This in turn strengthens relationships within the students' microsystem (e.g., with parents, peers, and teachers).

Peer support has been found to be an important variable in influencing a sense of school belonging (Goodenow \& Grady, 1993; Hamm \& Faircloth, 2005; Reschly, Busch, Betts, Deno, \& Long, 2009; Osterman, 2000). Libbey (2004) found this variable to be especially valid on measures that looked at school connectedness. The literature suggests that peers may facilitate adolescent students' feelings of being connected to school through social and academic support (Wentzel, 1998), acceptance (Wang \& Eccles, 2012), trust (Garcia-Reid, Reid, \& Peterson, 2005), or merely being present (e.g., having friends at school; Whitlock, 2006).

In the literature, parents are also found to play an important role in fostering school belonging (Brewster \& Bowen, 2004; Wang \& Eccles, 2012). Studies have shown that when parents provide support and show care, compassion, and encouragement towards academic endeavours, young people are more likely to exhibit greater connectedness to school (Benner et al., 2008; Brewster \& Bowen, 2004; Carter, McGee, Taylor, \& Williams, 2007; Wang \& Eccles, 2012).

The importance of teachers towards student outcomes has been widely studied (e.g., Anderman, 2002; Hattie, 2009; Wang \& Eccles, 2012). In a large-scale synthesis of research, Hattie (2009) ranked a teacher-student relationship (large effect size, $d=.72)$ as an important contributor to enhancing academic outcomes in students. In respect to school belonging, a study by Brewster and Bowen (2004) involving 699 high school students in the United States likewise established that while support from others (e.g., parents) was indeed beneficial for students, teacher support was the more important factor. This finding has been widely supported by other studies (e.g., Anderman, 2003; Garcia-Reid, 2007; Johnson, 2009; Sakiz, 2012).

Table 2 outlines examples of evidence-based strategies that specifically target the microsystem layer of the socio-ecological framework. Similar to Table 1, the approaches outlined are derived from the literature, as indicated in the table, and developed from key independent variables found in the literature that reported a significant and positive relationship with school belonging, with effect sizes ranging from medium to large strength, $r=.30$ to $r=.86$ (Cohen, 1988). Future research is needed to evaluate what specific interventions are needed for the themes of peer, parent, and teacher support to increase school belonging, but this table 
TABLE 2

Microsystem Level Practices Associated With Socio-Ecological Framework of School Belonging

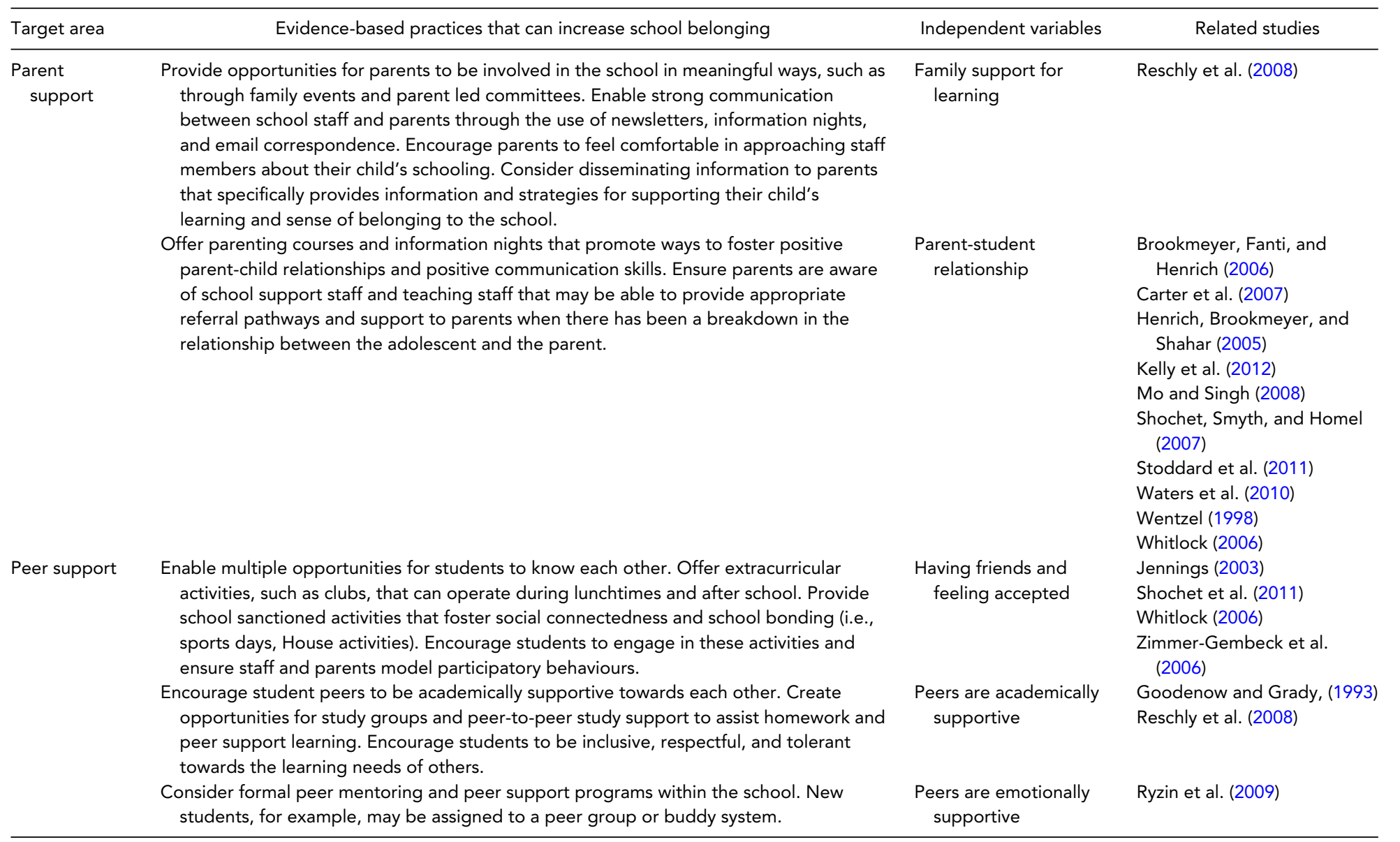


TABLE 2

Continued

\begin{tabular}{|c|c|}
\hline Target area & Evidence-based practices that can increase school belonging \\
\hline \multirow[t]{2}{*}{$\begin{array}{l}\text { Teacher } \\
\text { support }\end{array}$} & $\begin{array}{l}\text { Encourage teachers to provide pastoral support to students. Allow teachers time to be } \\
\text { available to students for personal support as well as academic support. }\end{array}$ \\
\hline & $\begin{array}{l}\text { Provide opportunities for teachers to get to know and understand their students (and at } \\
\text { least know them by name). This can show their students that they care about them. } \\
\text { Encourage teachers to seek feedback from students regarding their relationship and } \\
\text { rapport. Consider structuring classes, tutorials, or home groups within the school so } \\
\text { that teachers stay with the same students for a number of years. }\end{array}$ \\
\hline
\end{tabular}

Independent variables

Positive

student-teacher

relationship

Demonstrate fair practices within the classroom. Teachers should model respectful behaviour towards each other and to students, and implement reasonable and consistent disciplinary procedures that are agreed upon by students and other staff. Teachers can create student-led groups that provide mechanisms and pathways for student voice (e.g., student representative committee or a quality of teaching committee).

Offer support for the academic learning of students. Consider implementing a tutoring program for students to seek additional support over their academic learning or extended learning opportunities after school or during the school holidays. Teachers can provide students with autonomy, support, and involvement over their own learning. They can use learning interactions, visible learning practices, and formative feedback (Hattie, 2009).

Teachers show fairness

Academic support
Anderman (2003)

Bowen, Richman, and Bowen (1998)

Garcia-Reid (2007)

Garcia-Reid et al. (2005)

National Research Council

and the Institute of

Medicine (2004)

Reschly et al. (2008)

Shochet et al. (2007)

Shochet et al. (2011)

Waters et al. (2010)

Zimmer-Gembeck et al. (2006)

Sakiz (2012)

Patton et al. (2006)

Ryzin et al. (2009)

Wentzel (1998) 
represents some examples of approaches found in the previous literature worth exploring.

\section{Mesosystem}

The mesosystem can be seen as a byproduct of the interactions among the layers in the socio-ecological framework, and thus not only represents school processes, practices, policy, and pedagogy (Libbey, 2004; Saab, 2009), but also highlights the unique bidirectional interactions of the features within the microsystem layer. Tillery, Varjas, Roach, Kuperminc, and Meyers (2013) suggested that support for others within a school system (parents, peers, and teachers), may be made stronger or weaker by aspects of the mesosystem, such as the organisational structure and practices within the school. For example, schools promote safety at the mesosystem level through school rules and policies (Saab, 2009). Feeling safe at school has been identified in the literature as an important factor in a student's sense of belonging to school (CDC, 2009; Samdal et al., 1998; Wingspread Declaration on School Connections, 2004; Whitlock, 2006) and has also been found to be a central theme in measures of school connectedness and school belonging (Libbey, 2004).

School vision and mission statements are another example of one element of the mesosystem in the socio-ecological framework of school belonging. School vision and mission statements that outline a school's purpose may provide a school with an opportunity to create a shared vision in respect to how school belonging is prioritised. School vision and mission statements are, therefore, appropriate to include in a socioecological framework specific to a school setting due to their ability to offer a vehicle to promote a school's commitment to fostering school belonging. The development of school vision and mission statements that prioritise school belongingness can be created by schools to promote the school's approach to fostering school belonging and assist the development of goals and objectives around creating a stronger school community (CDC, 2009).

A number of studies have explored the importance of students' belief in school rules, discipline, and fairness upon school belonging (Brown \& Evans, 2002; Libbey, 2004). A review of the literature on the subject shows strong evidence for school engagement and retention in schools where discipline is enforced consistently and fairly (Finn \& Voelkl, 1993; Rumberger, 1995), therefore policies concerned with these variables should be an important consideration for all schools.

Multiple group memberships, such as those provided by extracurricular activities, are another example of a prevalent theme in the literature on school belonging. Researchers have found that a sense of school belonging can be positively influenced by the number of group memberships (Drolet \& Arcand, 2013) and number of extracurricular activities a student may subscribe to (Dotterer, McHale, \& Crouter, 2007; Libbey, 2004). One example is a study by Soria, Lingren Clark, and Coffin Koch (2011), who found that students' perceived sense of school belonging was influenced by whether or not they participated in extracurricular groups. The researchers investigated 1,865 students who participated in a range of student groups formed during orientation week activities. Results showed that students who attended these activities reported a higher sense of school belonging than those who did not. Furthermore, these students were more likely to have a higher grade point average than the respective cohort of non-participants. A similar relationship between a sense of belonging and 
extracurricular activities has been found in other research (Blomfield \& Barber, 2010; Dotterer et al., 2007; Knifsend \& Graham, 2012; Waters et al., 2010).

As well as fostering themes that positively correlate to school belonging at the individual and microsystem levels, it is clear from the literature that school leaders may also intervene at the mesosystem of the socio-ecological system. Table 3 outlines a set of evidence-based practices for schools derived from the past studies, as outlined below. These practices aim to foster school belonging primarily at the policy and practice level. The mesosystem level can include many variables, and it can be difficult for researchers to disentangle the multiple causal relationships. These practices should therefore be interpreted with some degree of caution and may serve as a source of further research.

\section{Exosystem}

The exosystem represents the community surrounding the school and encompasses the local neighbourhood, grandparents and extended families (although depending on the family structure they may also reside in the microsystem), local businesses, and community groups (Saab, 2009). Like the mesosystem, this layer is facilitated by the opportunities provided by schools that bring these groups together. Cemalcilar (2010) suggests that changing school-level practices at the exosystem level (or macro-level through reforms and laws) is a valid recommendation for interventions designed to foster school belonging. Some concrete examples would be for schools to connect with local businesses or other schools within the neighbourhood, or to implement school activities that involve the broader school community and the extended families of its students. Schools may also consider engaging with local community partners who are willing to provide a range of services within the school (e.g., a visiting GP, nurse health checks, dental services; CDC, 2009).

Less empirical information is available for the exosystem and macrosystem levels on school belonging (Brown Kirschman \& Karazsia, 2014). This is because it can be difficult to examine the exosystem or macrosystem, especially through studies concerned with preventative interventions like school belonging. These layers do not have a direct association with the student (or individual) where most studies are focused. Studies at the exosystem and macrosystem level on preventative interventions have traditionally engaged whole neighbourhoods at a considerable cost of time and resources (Brown Kirschman \& Karazsia, 2014). Furthermore, publically available data concerned with the exosystem are not available as they are for other systems (e.g., mesosystem, microsystem).

\section{Macrosystem}

The macrosystem layer represents broader legislation and public policies at the federal level and includes factors such as regulations, guidelines, and government-driven initiatives and data collection (Saab, 2009) as well as the historical (e.g., past events, climate, collective attitudes, and conditions) and cultural (e.g., language, norms, customs, beliefs) context unique to each school. The macrosystem can be influential in the processes of daily school practice, particularly on how schools orient their priorities and goals. The macrosystem layer may influence a student's sense of belonging, although further research is needed to substantiate this claim. One example for this assertion can be seen in Australia, where the use of NAPLAN testing has been controversial and intertwined with debates around teacher effectiveness and performance 
TABLE 3

Mesosystem Level Practices Associated with Socio-Ecological Framework of School Belonging

\begin{tabular}{|c|c|}
\hline Evidence-based practices & Related studies \\
\hline \multicolumn{2}{|c|}{ Develop a whole-school shared vision that prioritises school belonging } \\
\hline The development of a shared vision that prioritises school & Bryson (2004) \\
\hline belongingness can be created by schools to promote the & Legters, Balfanz, and McPartland \\
\hline school's approach to fostering school belonging and & $(2002)$ \\
\hline assist the development of goals and objectives around & Owings and Kaplan (2003) \\
\hline creating a stronger school community (CDC, 2009). A & Stemler, Bebell, and Sonnabend \\
\hline school's vision or mission statement may be an & (2011) \\
\hline appropriate vehicle to do this. & Teddlie and Reynolds (2000) \\
\hline \multicolumn{2}{|l|}{ Provide staff professional development } \\
\hline Provide teachers opportunities to receive professional & Allen, Pianta, Gregory, Mikami, and \\
\hline development in the area of student school belonging & Lun (2011) \\
\hline that will allow them to enhance their relationships with & \\
\hline students, foster a positive, safe, and fair classroom & \\
\hline environment, and implement a student-centred & \\
\hline pedagogy. & \\
\hline \multirow{2}{*}{$\begin{array}{l}\text { Facilitate staff development through mentoring programs } \\
\text { that are aimed at fostering student school belonging. }\end{array}$} & Ingersoll and Strong (2011) \\
\hline & National Research Council and the \\
\hline Mentoring programs have been found to encourage & Institute of Medicine (2004) \\
\hline teacher retention, increase job satisfaction, enhance & Quint, Bloom, Black, Stephens, and \\
\hline teaching quality, as well as have positive implications for & Akey (2005) \\
\hline
\end{tabular}
students' outcomes. Mentoring programs allow teachers to share strategies and techniques, learn from one another, and create a positive collaborative environment.

Sherin and Han (2004)

\section{School policies}

Apply policies and practices that are concerned with student safety, discipline, and fairness (e.g., anti-bullying policies) as these variables have been found to be important for fostering school belonging. Seek input from students, parents, school staff, and community members to develop school policies. Use policies to create foundations for school rules/classroom rules that can be promulgated to create a fair and safe school climate. Ensure they are understood, and implemented by all staff members.

Ensure policies and practices are created that are concerned with staff wellbeing and connectedness to the school, which may promote whole-school belongingness, not just student belongingness. If the wellbeing and belongingness of staff members is taken into account, teachers may be more effective educators, which may enhance the student-teacher relationship found to be an important theme for fostering school belonging. One example is the Positive Educational Practices (PEPS) Framework (Noble \& McGrath, 2008) which applies an optimistic approach to educational planning for school-wide wellbeing. Concepts such as positive emotions for students and teachers, social-emotional learning, focusing on ideal characteristics and strengths, and developing a sense of meaning are emphasised.

Noble (2006)

Noble and McGrath (2008) 
TABLE 3

Continued

\begin{tabular}{|c|c|}
\hline Evidence-based practices & Related studies \\
\hline \multicolumn{2}{|l|}{ School curricular and extracurricular activities } \\
\hline \multirow{4}{*}{$\begin{array}{l}\text { Create school curricular and extracurricular activities that } \\
\text { implement practices that foster school belonging. Allow for } \\
\text { sufficient curriculum time to be available to teach social and } \\
\text { emotional learning (SEL) found to increase school belonging. } \\
\text { An example of such a program is MindMatters, which is a } \\
\text { mental health program designed for Australian schools (Wyn }\end{array}$} & Frydenberg et al. (2009) \\
\hline & $\begin{array}{l}\text { Schonert-Reichl and Lawlor, } \\
\text { (2010) }\end{array}$ \\
\hline & Wyn et al. (2000) \\
\hline & \\
\hline \multicolumn{2}{|l|}{ Cahill, Holdsworth, Rowling, and Carson, 2000). One of the } \\
\hline \multicolumn{2}{|l|}{ objectives of the MindMatters program is to include mental } \\
\hline \multicolumn{2}{|l|}{ health promotion and education in the school curriculum. } \\
\hline \multirow{2}{*}{\multicolumn{2}{|c|}{$\begin{array}{l}\text { Another example could be for schools to introduce programs } \\
\text { and interventions in the school curriculum targeting the }\end{array}$}} \\
\hline & \\
\hline \multicolumn{2}{|l|}{ personal characteristics of students (e.g., coping skills and } \\
\hline \multicolumn{2}{|l|}{ resiliency skills) as well as mental health promotion initiatives } \\
\hline \multicolumn{2}{|l|}{ shown to foster school belonging. For instance, research using } \\
\hline \multicolumn{2}{|l|}{ interventions on coping techniques has demonstrated that } \\
\hline \multicolumn{2}{|l|}{ adaptive coping styles are positively related to perceived } \\
\hline \multicolumn{2}{|l|}{ sense of school belonging (Frydenberg et al., 2009). Another } \\
\hline \multicolumn{2}{|l|}{ example is Mindfulness-Based Education programs } \\
\hline \multicolumn{2}{|l|}{ (Schonert-Reichl \& Lawlor, 2010), adapted from the practice of } \\
\hline \multicolumn{2}{|l|}{ mindfulness to assist socio-emotional competence and } \\
\hline \multicolumn{2}{|l|}{ encourage positive emotions. } \\
\hline Extracurricular activities have been found to be an important & Blomfield and Barber (2010) \\
\hline theme for school belonging. Aim to provide opportunities for & Dotterer et al. (2007) \\
\hline \multicolumn{2}{|l|}{ lunch time and afterschool activities) and offer school } \\
\hline \multicolumn{2}{|l|}{ sanctioned groups for students to belong to (e.g., home } \\
\hline group/tutorial groups, school house groupings). & \\
\hline
\end{tabular}

Note: Practices are derived from the literature as indicated.

pay. A teacher's ability to implement a curriculum or bolster the study scores of students is not reported in the literature as a concern for students, yet it can often be a pressing burden for teachers in modern-day schools (Roffey, 2012; Thompson, 2013). This is perhaps a reflection of the pressure by governments and legislation to prioritise academic outcomes at the macrosystem level, above other important factors in the school system. Roffey's (2012) Wellbeing Australia Survey found that 'The additional stress on teachers working in unrealistic performance-driven environments has a negative impact on them, which in turn must impact [on the] health and wellbeing of the students in their classrooms' (p. 4). Increased teacher stress may affect the student-teacher relationship found to be important for fostering school belonging in this article. The absence of a positive student-teacher relationship may result in a reduction in school belonging. Therefore, schools should be mindful of the effect of government-driven initiatives and data collection and the effect this may have on the other socio-ecological layers common to schools.

Unless government bodies become aware of the growing pressure on schools and teachers from over-prioritising academic outcomes, schools may be reluctant to implement positive, proactive interventions related to school belonging or other areas (e.g., 
coping, resiliency, positive psychology) due to an already overcrowded curriculum (Thompson, 2013). Government bodies concerned with schools should therefore ensure that school belonging (and wellbeing more generally) is prioritised in major sources of information disseminated about schools; for example, including a school belonging measure on the My School website ${ }^{2}$. How students perceive their sense of belonging to their school may be information parents wish to seek about a school, in addition to academic scores. This is particularly relevant for addressing school dropout rates and student retention at school. Given that school life generally encompasses a diverse range of outcomes and experiences for students, it seems reasonable to argue that a school's educational practices should not be reduced to a set of standardised scores based on one element of the school's performance (Hardy \& Boyle, 2012). At the school level, schools must be mindful of these macrosystem level influences from government reform and policy. It is paramount that schools set realistic and inclusive expectations for academic outcomes for their students, while being mindful of the needs of teachers (Roffey, 2012).

\section{Strengths and Limitations of the Framework}

The socio-ecological framework of school belonging is based on empirical evidence derived from past literature. The framework is designed as a comprehensive way for schools to foster school belonging. While the framework itself has been developed from peer-reviewed empirical studies, the inclusion of mainly correlational findings means that the direction of the relationship between the themes found to be strongly correlated with school belonging require further analysis. An important caveat of the framework, therefore, is that the influence of themes associated with school belonging cannot be regarded as causal.

\section{Future Research}

The framework and suggested evidence-based school practices would be strengthened if they were tested or evaluated using other methods of research. For example, a case study would refine the understanding of how context affects: (a) what practices are implemented, (b) how the practices are implemented, and (c) the success of the practices. A deeper understanding of the evidence-based socio-ecological framework and accompanying school practices would be gained by investigating the experiences, values, and preferences of school leaders, educators, students, and school psychologists (Dollaghan, 2004). Further research should aim to use longitudinal designs with objective measures (e.g., observation) for a more detailed understanding of school belonging.

Questions also remain about how school belonging may differ within specific populations. How does the framework apply to young people who do not belong? How does the framework apply to minority groups? While it is clear that social support is essential to improve belonging among students, this appears to be even more salient for minority groups; for example, individuals of different racial and ethnic backgrounds, persons with disabilities (McMahon et al., 2008), and students who identify themselves as having GLBTQI orientation (Aerts, Van Houtte, Dewaele, Cox, \& Vincke, 2012). For these students, the acceptance of their peers, teachers, and parents has been found to be an important variable in developing prosocial behaviour and a positive attitude towards school (Galliher, Rostosky, \& Hughes, 
2004). Assessing the socio-ecological framework of school belonging's usefulness for specific populations can be examined by future research. Further investigation of the relationship between the broader school community, neighbourhoods, and extended families on the perceived sense of belonging by young people may yield more information on how school belonging can be fostered through a whole-school approach.

Empirical evaluation of the framework in different samples would allow identification of the direction of the relationships of the various individual, microsystem, mesosystem, exosystem, and macrosystem levels with school belonging, thus creating a clearly identified pathway for fostering this construct (e.g., what layers are interdependent, how are they weighted, and what combinations are especially important for school belonging to occur?). Therefore, further research is needed to empirically validate the framework and associated evidence-based school practices and further understand the importance of school belonging and how to increase and/or maintain it in secondary school settings.

\section{Conclusions}

This article presented a new socio-ecological framework of school belonging using an ecologically oriented school perspective. The socio-ecological framework of school belonging, in its present form, extends Bronfenbrenner's (1979) ecological framework for human development and represents school belonging as a multidimensional construct. Schools may be better equipped to prioritise school belonging more effectively if they have the appropriate and accessible resources by which they could base interventions on fostering and maintaining school belonging at multiple levels. Therefore, the socio-ecological framework of school belonging aims to bridge research and practice through equipping schools with evidence-based information on how school belonging can be increased or maintained.

\section{Financial Support}

This work did not receive financial support.

\section{Conflict of Interest}

None.

\section{Ethical Standards}

This review did not involve human and/or animal experimentation.

\section{Endnotes}

1 In 2003 the Centers for Disease Control and Prevention's (CDC) Division of Adolescent and School Health, and the Johnson Foundation convened an international gathering of educational leaders and researchers at the Wingspread conference centre in the United States. The Wingspread Declaration on School Connections (2004) was the result of a 'detailed review of research and in-depth discussions across two days' (p. 233).

2 My School Website (ACARA, 2009), which publishes National Assessment Program — Literacy and Numeracy (NAPLAN) results, a standardised measure of academic achievement, for all primary and secondary schools in the country 


\section{References}

Aerts, S., Van Houtte, M., Dewaele, A., Cox, N., \& Vincke, J. (2012). Sense of belonging in secondary schools: A survey of LGB and heterosexual students in Flanders. Journal of Homosexuality, 59, 90-113.

Allen, J.P., Pianta, R.C., Gregory, A., Mikami, A.Y., \& Lun, J. (2011). An interaction-based approach to enhancing secondary school instruction and student achievement. Science, 333, 1034-1037.

Allen, K., \& Bowles, T. (2013). Belonging as a guiding principle in the education of adolescents. Australian Journal of Educational \& Developmental Psychology, 12, 108-119.

Anderman, E.M. (2002). School effects on psychological outcomes during adolescence. Journal of Educational Psychology, 94, 795-809.

Anderman, L.H. (2003). Academic and social perceptions as predictors of change in middle school students' sense of school belonging. Journal of Experimental Education, 72, 5-22.

Appleton, J.J., Christenson, S.L., Kim, D., \& Reschly, A.L. (2006). Measuring cognitive and psychological engagement: Validation of the student engagement instrument. Journal of School Psychology, 44, 427445.

Bailey, M., \& McLaren, S. (2005). Physical activity alone and with others as predictors of sense of belonging and mental health in retirees. Aging \& Mental Health, 9, 82-90.

Battistich, V., Schaps, E., Watson, M., \& Solomon, D. (1996). Prevention effects of the child development project early findings from an ongoing multisite demonstration trial. Journal of Adolescent Research, $11,12-35$.

Baumeister, R.F., \& Leary, M.R. (1995). The need to belong: Desire for interpersonal attachments as a fundamental human motivation. Psychological Bulletin, 11, 497-529.

Benner, A.D., Graham, S., \& Mistry, R.S. (2008). Discerning direct and mediated effects of ecological structures and processes on adolescents' educational outcomes. Developmental Psychology, 44, 840854.

Beyond Blue. (2014). SenseAbility communications portal. Retrieved from http://www.beyondblue.org.au/ resources/schools-and-universities/secondary-schools-and-tertiary/senseability

Blomfield, C., \& Barber, B.L. (2010). Australian adolescents' extracurricular activity participation and positive development: Is the relationship mediated by peer attributes? Australian Journal of Educational \& Developmental Psychology, 10, 114-128.

Boerema, A.J. (2006). An analysis of private school mission statements. Peabody Journal of Education, 81, 180-202.

Bowen, G., Richman, J.M., \& Bowen, N.K. (1998). Sense of school coherence, perceptions of danger at school, and teacher support among youth at risk of school failure. Child \& Adolescent Social Work Journal, 15, 273-286.

Brandon, C., \& Ivens, C. (2012). Thinking skills for peak performance: Student workbook. Macmillan Education Australia. Retrieved from http://www.macmillan.com.au/secondary/onix/isbn/9781420229356

Brechwald, W.A., \& Prinstein, M.J. (2011). Beyond homophily: A decade of advances in understanding peer influence processes. Journal of Research on Adolescence, 21, 166-179.

Brendtro, L., Brokenleg, M., \& Van Bockern, S. (2002). Reclaiming youth at risk: Our hope for the future (rev. ed.). Bloomington, IN: National Educational Service.

Brewster, A.B., \& Bowen, G.L. (2004). Teacher support and the school engagement of Latino middle and high school students at risk of school failure. Child and Adolescent Social Work Journal, 21, 47-67.

Bronfenbrenner, U. (1979). The ecology of human development: Experiments by nature and design. Cambridge, MA: Harvard University Press.

Brookmeyer, K.A., Fanti, K.A., \& Henrich, C.C. (2006). Schools, parents, and youth violence: A multilevel, ecological analysis. Journal of Clinical Child \& Adolescent Psychology, 35, 504-514.

Brophy, J. (2004). Motivating students to learn (2nd ed.). Mahwah, NJ: Lawrence Erlbaum Associates.

Brown Kirschman, K.J., \& Karazsia, B.T. (2014). The role of pediatric psychology in health promotion and injury prevention. In M.C. Roberts, B. Aylward, \& Y. Wu (Eds.), Clinical practice of pediatric psychology (pp. 136-138). New York, NY: Guilford Press. 
Brown, R., \& Evans, W.P. (2002). Extracurricular activity and ethnicity: Creating greater school connection among diverse student populations. Urban Education, 37, 41-58. doi:10.1177/0042085902371004

Bryson, J.M. (2004). What to do when stakeholders matter: Stakeholder identification and analysis techniques. Public management review, 6, 21-53.

Caraway, K., Tucker, C.M., Reinke, W.M., \& Hall, C. (2003). Self-efficacy, goal orientation, and fear of failure as predictors of school engagement in high school students. Psychology in the Schools, 40, 417-428.

Carter, M., McGee, R., Taylor, B., \& Williams, S. (2007). Health outcomes in adolescence: Associations with family, friends and school engagement. Journal of Adolescence, 30, 51-62.

Centers for Disease Control and Prevention (CDC). (2009). School connectedness: Strategies for increasing protective factors among youth. Atlanta, GA: U.S. Department of Health and Human Services.

Cemalcilar, Z. (2010). Schools as socialization contexts: Understanding the impact of school climate factors on students' sense of school belonging. Applied Psychology: An International Review, 59, 243 272.

Cohen, J. (1988). Statistical power analysis for the behavioral sciences (2nd ed.). Hillsdale, NJ: Lawrence Erlbaum.

Cole, P., Llera, S., \& Pemberton, C. (2009). Emotional instability, poor emotional awareness, and the development of borderline personality. Development and Psychopathology, 21, 1293-1310.

Collaborative for Academic, Social, and Emotional Learning (CASEL). (2003). Safe and sound: An educational leaders' guide to evidence-based social and emotional learning (SEL) programs. Retrieved from www.casel.org

Connell, J.P., \& Wellborn, J.G. (1991). Competence, autonomy and relatedness: A motivational analysis of self-system processes. In M.R. Gunnar \& L.A. Sroufe (Eds.), Minnesota Symposium on Child Psychology (vol. 23, pp. 43-77). Hillsdale, MI: Lawrence Erlbaum Associates.

Daley, A.J., \& Buchanan, J. (1999). Aerobic dance and physical self-perceptions in female adolescents: Some implications for physical education. Research Quarterly for Exercise and Sport, 70, 196200.

Davis, K. (2012). Friendship 2.0: Adolescents' experiences of belonging and self-disclosure online. Journal of Adolescence, 35, 1527-1536.

Dollaghan, C. (2004). Evidence-based practice: Myths and realities. The ASHA Leader, 12, 4-5. Retrieved from http://www.asha.org/publications/leader/2004/040413/f040413a1.htm

Donovan, J. (2011). The role for marketing in public health change programs. Australian Review of Public Affairs, 10, 23-40.

Dotterer, A.M., McHale, S.M., \& Crouter, A.C. (2007). Implications of out-of-school activities for school engagement in African American adolescents. Journal of Youth and Adolescence, 36, 391-401.

Drolet, M., \& Arcand, I. (2013). Positive development, sense of belonging, and support of peers among early adolescents: Perspectives of different actors. International Education Studies, 6, 29-38.

Dweck, C.S. (1986). Motivational processes affecting learning. American Psychologist, 41, 1040-1048.

Education Development Center. (2008). School connectedness and meaningful student participation. Washington, DC: U.S. Department of Education. Retrieved from http://www.ed.gov/admins/lead/safety/training/connect/index.html

Faircloth, B.S. (2009). Making the most of adolescence: Harnessing the search for identity to understand classroom belonging. Journal of Adolescent Research, 24, 321-348.

Finn, J.D., \& Voelkl, K.E. (1993). School characteristics related to student engagement. Journal of Negro Education, 62, 249-268.

Friedman, M. (2007). The role of government in education. In R. Current (Ed.), Philosophy of education (pp. 194-199). Oxford, U.K.: Blackwell.

Frydenberg, E. (2011). Coping for Success Program: Skills for everyday living. Retrieved from http://www.coop.com.au/coping-for-success-program-skills-for-everyday-living/9780734027412

Frydenberg, E., Care, E., Freeman, E., \& Chan, E. (2009). Interrelationships between coping, school connectedness and wellbeing. Australian Journal of Education, 53, 261-276. 
Galliher, R.V., Rostosky, S.S., \& Hughes, H.K. (2004). School belonging, self-esteem, and depressive symptoms in adolescents: An examination of sex, sexual attraction status, and urbanicity. Journal of Youth and Adolescence, 33, 235-245.

Garcia-Reid, P. (2007). Examining social capital as a mechanism for improving school engagement among low income hispanic girls. Youth \& Society, 39, 164-181.

Garcia-Reid, P.G., Reid, R.J., \& Peterson, N.A. (2005). School engagement among Latino youth in an urban middle school context: Valuing the role of social support. Education and Urban Society, 37, 257275.

Gillen-O’Neel, C., \& Fuligni, A. (2013). A longitudinal study of school belonging and academic motivation across high school. Child Development, 84, 678-692. doi:10.1111/j.1467-8624.2012.01862.x

Goodenow, C. (1992). Strengthening the links between educational psychology and the study of social contexts. Educational Psychologist, 27, 177-196.

Goodenow, C., \& Grady, K.E. (1993). The relationship of school belonging and friends' values to academic motivation among urban adolescent students. Journal of Experimental Education, 62, 60-71.

Guthrie, J.T., \& Davis, M.H. (2003). Motivating struggling readers in middle school through an engagement model of classroom practice. Reading \& Writing Quarterly, 19, 59-85.

Hagerty, B.M., Lynch-Sauer, J., Patusky, K., Bouwsema, M., \& Collier, P. (1992). Sense of belonging: A vital mental health concept. Archives of Psychiatric Nursing, 6, 172-177.

Hagerty, B.M., Williams, R.A., \& Oe, H. (2002). Childhood antecedents of adult sense of belonging. Journal of Clinical Psychology, 58, 793-801.

Hale, C.J., Hannum, J.W., \& Espelage, D.L. (2005). Social support and physical health: The importance of belonging. Journal of American College Health, 53, 276-284.

Hamm, J.V., \& Faircloth, B.S. (2005). The role of friendship in adolescents' sense of school belonging. New Directions for Child and Adolescent Development, 2005, 61-78. doi:10.1002/cd.121

Hardy, I., \& Boyle, C. (2011). My School? Critiquing the abstraction and quantification of education. Asia-Pacific Journal of Teacher Education, 39, 211-222. DOI: 10.1080/1359866X.2011.588312.

Hattie, J. (2009). Visible learning: A synthesis of meta-analyses relating to achievement. London, England: Routledge.

Hawkins, J.D., Von Cleve, E., \& Catalano, Jr, R.F. (1991). Reducing early childhood aggression: Results of a primary prevention program. Journal of the American Academy of Child and Adolescent Psychiatry, $30,208-17$.

Hawkins, J.D., \& Weis, J.G. (1985). The social development model: An integrated approach to delinquency prevention. Journal of Primary Prevention, 6, 73-97.

Heaven, P.C., Mak, A., Barry, J., \& Ciarrochi, J. (2002). Personality and family influences on adolescent attitudes to school and self-rated academic performance. Personality and Individual Differences, 32, 453-462.

Henrich, C.C., Brookmeyer, K.A., \& Shahar, G. (2005). Weapon violence in adolescence: Parent and school connectedness as protective factors. Journal of Adolescent Health, 37, 306-312.

Hirschkorn, M. \& Geelan, D. (2008). Bridging the research-practice gap: Research translation and/or research transformation. Alberta Journal of Educational Research, 54, 1-13.

Hurtado, S., \& Carter, D.F. (1997). Effects of college transition and perceptions of the campus racial climate on Latino college students' sense of belonging. Sociology of Education, 70, 324-345.

Ingersoll, R., \& Strong, M. (2011). The impact of induction and mentoring programs for beginning teachers: A critical review of the research. Review of Education Research, 81, 201-233.

Jennings, G. (2003). An exploration of meaningful participation and caring relationships as contexts for school engagement. The California School Psychologist, 8, 43-52.

Johnson, L.S. (2009). School contexts and student belonging: A mixed methods study of an innovative high school. The School Community Journal, 19, 99-119.

Juvonen, J. (2006). Sense of belonging, social bonds, and school functioning. In P.A. Alexander \& P.H. Winne (Eds.), Handbook of educational psychology (2nd ed., pp. 655-674). Mahwah, MH: Lawrence Erlbaum. 
Kaminski, J.W., Puddy, R.W., Hall, D.M., Cashman, S.Y., Crosby, A.E., \& Ortega, L.A. (2010). The relative influence of different domains of social connectedness on self-directed violence in adolescence. Journal of Youth and Adolescence, 39, 460-473.

Kelly, A.B., O’Flaherty, M., Toumbourou, J.W., Homel, R., Patton, G.C., White, A., \& Williams, J. (2012). The influence of families on early adolescent school connectedness: Evidence that this association varies with adolescent involvement in peer drinking networks. Journal of Abnormal Child Psychology, 40, 437-447.

Klem, A.M., \& Connell, J.P. (2004). Relationships matter: Linking teacher support to student engagement and achievement. Journal of School Health, 74, 262-273.

Knifsend, C., \& Graham, S. (2012). Too much of a good thing? How breadth of extracurricular participation relates to school-related affect and academic outcomes during adolescence. Journal of Youth and Adolescence, 41, 379-389. doi:10.1007/s10964-011-9737-4.

Kuperminc, G.P., Leadbeater, B.J., \& Blatt, S.J. (2001). School social climate and individual differences in vulnerability to emotional instability among middle school students. Journal of School Psychology, 39, 141-159.

Lee, R.M., \& Robbins, S.B. (2000). Understanding social connectedness in college women and men. Journal of Counseling \& Development, 78, 484-491. doi:10.1002/j.1556-6676.2000.tb01932.x

Legters, N., Balfanz, R., \& McPartland, J. (2002). Solutions for failing high schools: Converging visions and promising models. Washington, DC: U.S. Department of Education.

Libbey, H.P. (2004). Measuring student relationships to school: Attachment, bonding, connectedness, and engagement. Journal of School Health, 74, 275-283.

Lonczak, H.S., Abbott, R.D., Hawkins, J.D., Kosterman, R., \& Catalano, R. (2002). The effects of the Seattle social development project: Behavior, pregnancy, birth, and sexually transmitted disease outcomes by age 21. Archives of Pediatric Adolescent Medicine, 156, 438-447.

McClelland, J.L. (1987). The case for interactions in language processing. In M. Coltheart (Ed.), Attention and performance XII: The psychology of reading (pp. 3-36). Hillsdale, NJ: Lawrence Erlbaum Associates.

McMahon, S., Parnes, A., Keys, C. \& Viola, J. (2008). School belonging among low-income urban youth with disabilities: Testing a theoretical model. Psychology in the Schools, 45, 387-401.

McNeely, C.A., Nonnemaker, J.M., \& Blum, R.W. (2002). Promoting school connectedness: Evidence from the National Longitudinal Study of Adolescent Health. Journal of School Health, 72, 136-146.

Malti, T., \& Noam, G.G. (2009). A developmental approach to the prevention of adolescents' aggressive behavior and the promotion of resilience. International Journal of Developmental Science, 3, 235-246.

Mo, Y., \& Singh, K. (2008). Parents' relationships and involvement: Effects on students' school engagement and performance. Research in Middle Level Education Online, 31, 1-11.

National Research Council and the Institute of Medicine. (2004). Engaging schools: Fostering high school students' motivation to learn. Washington, DC: National Academies Press.

Nielsen, T.W. (2011). A curriculum of giving for student wellbeing and achievement — 'How to wear leather sandals on a rough surface'. In D. Wright, C. Camden-Pratt, \& S. Hill (Eds.), Social ecology: Applying ecological understanding to our lives and our planet (pp. 151-164). Stroud, U.K.: Hawthorn Press.

Noble, T. (2006). Core components of a school-wide safe schools curriculum. In H. McGrath \& T. Noble (Eds.), Bullying solutions. Evidence-based approaches to bullying in Australian schools (pp. 36-62). Melbourne, Australia: Pearson Education.

Noble, T., \& McGrath, H. (2008). The positive educational practices framework: A tool for facilitating the work of educational psychologists in promoting pupil wellbeing. Educational and Child Psychology, $25,119-134$.

Nutbrown, C., \& Clough, P. (2009). Citizenship and inclusion in the early years: understanding and responding to children's perspectives on 'belonging'. International Journal of Early Years Education, 17, 191-206. doi:10.1080/09669760903424523

O'Connor, M. (2010). Life beyond school: The role of school bonding in preparing adolescents for adulthood. Independence, 35, 24-28. 
O'Connor, M., Sanson, A., \& Frydenberg, E. (2012). The relationship between positive development during the transition to adulthood and temperament, personality, and educational outcomes. In E. Frydenberg \& G. Reevy (Eds.), Personality, stress, and coping: Implications for education (vol. vi, pp. 111-130). Charlotte, NC: Information Age.

Osterman, K.F. (2000). Students' need for belonging in the school community. Review of Educational Research, 70, 323-367.

Owings, W.A., \& Kaplan, L.S. (2003). Best practices, best thinking, and emerging issues in school leadership. Thousand Oaks, CA: Corwin Press.

Patton, G.C., Bond, L., Carlin, J.B., Thomas, L., Butler, H., Glover, S., . . \& Bowes, G. (2006). Promoting social inclusion in schools: a group-randomized trial of effects on student health risk behavior and well-being. American Journal of Public Health, 96, 1582-1587.

Poulton, R., Caspi, A., \& Milne, B.J. (2002). Association between children's experience of socioeconomic disadvantage and adult health: A life-course study. Lancet, 360, 1640-1645.

Proctor, C., Tsukayama, E., Wood, A.M., Maltby, J., Eades, J.F., \& Linley, P.A. (2011). Strengths gym: The impact of a character strengths-based intervention on the life satisfaction and well-being of adolescents. Journal of Positive Psychology, 6, 377-388.

Quint, J., Bloom, H., Black, A., Stephens, L., \& Akey, T. (2005). The challenge of scaling up educational reform. Findings and lessons from First Things First. New York, NY: MDRC.

Reschly, A.L., Busch, T.W., Betts, J., Deno, S.L., \& Long, J.D. (2009). Curriculum-based measurement oral reading as an indicator of reading achievement: A meta-analysis of the correlational evidence. Journal of School Psychology, 47, 427-469.

Reschly, A.L., Huebner, E.S., Appleton, J.J., \& Antaramian, S. (2008). Engagement as flourishing: The contribution of positive emotions and coping to adolescents' engagement at school and with learning. Psychology in the Schools, 45, 419-431.

Roche, C., \& Kuperminc, G.P. (2012). Acculturative stress and school belonging among Latino youth. Hispanic Journal of Behavioral Sciences, 34, 61-76.

Roffey, S. (2012). Pupil wellbeing — teacher wellbeing: Two sides of the same coin? Educational \& Child Psychology, 29, 8-17.

Rogers, C.R. (1951). Client-centered therapy; its current practice, implications, and theory. Oxford, England: Houghton Mifflin.

Rowe, F., \& Stewart, D. (2011). Promoting connectedness through whole-school approaches: Key elements and pathways of influence. Health Education, 111, 49-65.

Rowe, F., Stewart, D., \& Patterson, C. (2007). Promoting school connectedness through whole-school approaches. Health Education, 107, 524-542.

Rumberger, R. (1995). Dropping out of middle school: A multilevel analysis of students and schools. American Educational Research Journal, 32, 583-625.

Ryan, M. (1995). Psychological needs and the facilitation of integrative processes. Journal of Personality, $63,397-427$.

Ryan, R.M., \& Deci, E.L. (2000). Self-determination theory and the facilitation of intrinsic motivation, social development, and wellbeing. American Psychologist, 55, 68-78.

Ryan, R.M., Stiller, J.D., \& Lynch, J.H. (1994). Representations of relationships to teachers, parents, and friends as predictors of academic motivation and self-esteem. Journal of Early Adolescence, 14, $226-$ 249.

Ryzin, M.J., Gravely, A.A., \& Roseth, C.J. (2009). Autonomy, belongingness, and engagement in school as contributors to adolescent psychological wellbeing. Journal of Youth and Adolescence, 38, $1-12$.

Saab, H. (2009). The school as a setting to promote student health. Retrieved from http://qspace.library.queensu.ca

Sakiz, G. (2012). Perceived instructor affective support in relation to academic emotions and motivation in college. Educational Psychology: An International Journal of Experimental Educational Psychology, 32, 63-79. 
Samdal, O., Nutbeam, D., Wold, B., \& Kannas, L. (1998). Achieving health and educational goals through schools: A study of the importance of the climate and students' satisfaction with school. Health Education Research, 3, 383-397.

Sari, M. (2012). Sense of school belonging among elementary school students. Çukurova University Faculty of Education Journal, 41, 1-11.

Schonert-Reichl, K. \& Lawlor, M. (2010). The effects of a mindfulness-based education program on preand early adolescents' well-being and social and emotional competence. Mindfulness, 1, 137-151.

Seligman, M. (2011). Flourish. New York, NY: Free Press.

Sharma, M., \& Romas, J.A. (2008). Theoretical foundations of health: Education and health promotion. Sudbury, MA: Jones \& Bartlett.

Sherin, M., \& Han, S. (2004). Teacher learning in the context of a video club. Teaching and Teacher Education, 20, 163-183.

Shochet, I.M., Dadds, M.R., Ham, D., \& Montague, R. (2006). School connectedness is an underemphasized parameter in adolescent mental health: Results of a community prediction study. Journal of Clinical Child and Adolescent Psychology, 35, 170-179.

Shochet, I.M., Smith, C.L., Furlong, M.J., \& Homel, R. (2011). A prospective study investigating the impact of school belonging factors on negative affect in adolescents. Journal of Clinical Child \& Adolescent Psychology, 40, 586-595. doi:10.1080/15374416.2011.581616

Shochet, I.M., Smyth, T.L., \& Homel, R. (2007). The impact of parental attachment on adolescent perception of the school environment and school connectedness. Australian and New Zealand Journal of Family Therapy, 28, 109-118.

Sirin, S.R., \& Rogers-Sirin, L. (2004). Exploring school engagement of middle-class African American adolescents. Youth \& Society, 35, 323-340.

Soria, K.M., Lingren Clark, B., \& Coffin Koch, L. (2013). Investigating the academic and social benefits of extended new student orientations for first-year students. The Journal of College Orientation and Transition, 20, 33-45.

Stemler, S., Bebell, D., \& Sonnabend, L.A. (2011). Using school mission statements for reflection and research. Educational Administration Quarterly, 47, 383-420.

Stoddard, S.A., McMorris, B.J., \& Sieving, R.E. (2011). Do social connections and hope matter in predicting early adolescent violence? American Journal of Community Psychology, 48, 247-256.

Teddlie, C., \& Reynolds, D. (2000). The international handbook of school effectiveness research. New York, NY: Falmer Press.

Thompson, G. (2013). NAPLAN, My School and accountability: Teacher perceptions of the effects of testing. The International Education Journal: Comparative Perspectives, 12, 62-84.

Tillery, A.D., Varjas, K., Roach, A.T., Kuperminc, G.P., \& Meyers, J. (2013). The importance of adult connections in adolescents' sense of school belonging: Implications for schools and practitioners. Journal of School Violence, 12, 134-155. doi:10.1080/15388220.2012.762518

Vallerand, R.J. (1997). Towards a hierarchical model of intrinsic and extrinsic motivation. Advances in Experimental Social Psychology, 29, 271-360.

Wadsworth, M.E., Thomsen, A.H., Saltzman, H., Connor-Smith, J.K., \& Compas, B.E. (2001). Coping with stress during childhood and adolescence: Problems, progress, and potential in theory and research. Psychological Bulletin, 127, 87-127.

Walker, C.O. (2012). Student perceptions of classroom achievement goals as predictors of belonging and content instrumentality. Social Psychology of Education, 15, 97-107.

Wallace, T.L., Ye, F., \& Chhuon, V. (2012). Subdimensions of adolescent belonging in high school. Applied Developmental Science, 16, 122-139.

Wang, M., \& Eccles, J.S. (2012). Social support matters: Longitudinal effects of social support on three dimensions of school engagement from middle to high school. Child Development, 83, 877-895.

Waters, S., Cross, D., \& Runion, K. (2009). Social and ecological structures supporting adolescent connectedness to school: A theoretical model. Journal of School Health, 79, 516-524. doi:10.1111/j.1746-1561.2009.00443.x 
Waters, S., Cross, D., \& Shaw, T. (2010). Does the nature of schools matter? An exploration of selected school ecology factors on adolescent perceptions of school connectedness. British Journal of Educational Psychology, 80, 381-402. doi:10.1348/000709909X484479.

Wentzel, K.R. (1998). Social relationships and motivation in middle school: The role of parents, teachers, and peers. Journal of Educational Psychology, 90, 202-209.

West, P., Sweeting, H., \& Leyland, A. (2004). School effect on pupils' health behaviours: Evidence in support of the health promoting school. Research Papers in Education, 19, 261-291. doi:10.1080/0267152042000247972

Whitlock, J. (2006). The role of adults, public space, and power in adolescent community connectedness. Journal of Community Psychology, 35, 499-518.

Wilkinson-Lee, A.M., Zhang, Q., Nuno, V.L., \& Wilhelm, M.S. (2011). Adolescent emotional distress: The role of family obligations and school connectedness. Journal of Youth and Adolescence, 40, 221-230. doi:10.1007/ s10964-009-9494-9

Williams, K.L., \& Galliher, R.V. (2006). Predicting depression and self-esteem from social connectedness, support, and competence. Journal of Social and Clinical Psychology, 25, 855-874. doi:10.1521/jscp.2006.25.8.855

Wingspread Declaration on School Connections. (2004). Journal of School Health, 74, 233-234.

Wyn, J., Cahill, H., Holdsworth, R., Rowling, L., \& Carson, S. (2000). MindMatters, a whole-school approach promoting mental health and wellbeing. Australian and New Zealand Journal of Psychiatry, $34,594-601$.

Zimmer-Gembeck, M., Chipuer, H., Hanisch, M., Creed, P., \& McGregor, L. (2006). Relationships at school and stage-environment fit as resources for adolescent engagement and achievement. Journal of Adolescence, 29, 911-933. 